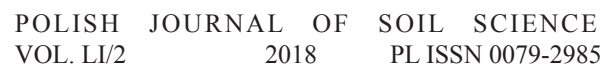

DOI: $10.17951 / \mathrm{pjss} / 2018.51 .2 .271$

\author{
RENATA GAMRAT*, TOMASZ TOMASZEWICZ**, \\ JUSTYNA CHUDECKA**, SŁAWOMIR STANKOWSKI***, \\ MARIOLA WRÓBEL $* * * *$, GRZEGORZ NOWAK*****
}

\title{
PLANT COMMUNITIES IN THE LYSIMETER EXPERIMENT OF ASH RECLAMATION IN THE DOLNA ODRA POWER STATION IN NOWE CZARNOWO (POLAND)
}

Abstract. The aim of the study was to determine the type and origin of plant communities on an area of 4 lysimeters $\left(35 \mathrm{~m}^{2}\right.$ each) filled with ash and covered with two superlayers 12 years after the beginning of the experience. The paper presents the species of grasses sown in 2003, their sward participation then and the florist status in 2015. Phytosociological records were taken using the Braun-Blanquet's method, distinguished plant communities, the syngenesis of the recognized phytocoenoses was defined. The results allowed to determine the advantage of the ruderal synanthropic communities: Artemisio-Tanacetetum vulgaris Br-B1. 1931 corr. 1949 (in L-2), Leonuro-Ballotetum nigrae (in L-3), a community with Rubus caesius (in L-4) over the nat-

* Department of Ecology, Environmental Protection and Management, West Pomeranian University of Technology in Szczecin, Słowackiego 17, 71-434 Szczecin, Poland. Corresponding author: R. Gamrat, e-mail: renata.gamrat@zut.edu.pl

** Department of Soil Science, Grassland and Environmental Chemistry, West Pomeranian University of Technology in Szczecin, Słowackiego 17, 71-434 Szczecin, Poland.

*** Department of Agronomy, West Pomeranian University of Technology in Szczecin, Papieża Pawła VI 3, 71-459 Szczecin, Poland.

**** Department of Botany and Nature Protection, West Pomeranian University of Technology in Szczecin, Słowackiego 17, 71-434 Szczecin, Poland.

***** Department of Meteorology and Landscape Architecture, West Pomeranian University of Technology in Szczecin, Papieża Pawła VI 3, 71-459 Szczecin, Poland. 
ural auxochoric Calamagrostietum epigeji Juraszek 1928 (in L-1). Their current state is referred to as a hull form. However, due to the presence of the expansive species characteristic of the above-mentioned communities, continued development can be expected towards fully developed phytocoenoses. The thesis founded about the influence of the neighboring forest communities on the species composition of the vegetation of the subject has not been confirmed. There were only three forest and scrub species with a negligible sward participation.

Keywords: transformation of vegetation, synanthropic communities, ashes

\section{INTRODUCTION}

Nature abhors the emptiness, thus sooner or later, every free space will be covered with vegetation. With a wide ecological tolerance or specific structure, it has the ability to colonize the natural areas characterized by extreme habitat (climate, edafic) conditions, as well as degraded areas due to human activity. The rate of available areas colonization by vegetation is dependent on the intensity of external factors (Woch et al. 2013, Ciećko et al. 2015, Żołnierz et al. 2016). This is particularly evident in the anthropogenic areas resulting from an intensive human economic activity. These areas, after the loss of human pressure, are colonized by newly formed synanthropic or ruderal communities (Balcerkiewicz and Pawlak 2008, Gamrat et al. 2016).

Areas, where ash is stored and used to reclamation, are also subject to plant succession, though perhaps not as fast as in areas with favorable ecological conditions (Majtkowski and Majtkowska 2012, Bajor et al. 2014). Much of the species inhabiting these habitats come from surrounding areas, or the so-called soil seed bank (Woch 2012).

Lysimeter areas tested in the present work are adjacent to heavily shaded forest areas dominated by Alnus glutinosa Gaertn. It was assumed, therefore, that eight years after the cessation of human interference, forest and scrub species will dominate on the studied soils.

The aim of the study was to determine the type and origin of plant communities developed on the surface of reclaimed ash using organic matter 12 years after the experiment set in lysimeters.

\section{MATERIALS AND METHODS}

The experimental object was founded in 2002 in the Dolna Odra Power Station in Nowe Czarnowo (Poland; 5311'40”N, 14²9'30”E). Four lysimeters were built within its area, each with an area of $35 \mathrm{~m}^{2}$. After filling them with furnace ashes, the superlayer of $40 \mathrm{~cm}$ thickness was put on its surface having to play the function of the humus layer. In the first two lysimeters (L-1 and L-2), it 
was a mixture of low peat and ash in volume ratio of $1: 3$, whereas in the remaining ones (L-3 and L-4), the superlayer consisted of shredded conifer bark, loose sand, compost produced by GWDA method, and fermented municipal sewage sludge (having a composition per dry matter: $70 \%$ sludge, $30 \%$ straw) in volume ratio of 1:1:2:4 (Stankowski et al. 2005). The paper presents the species composition of grass mixtures sown in 2003 and then participation in the sward (Stankowski et al. 2005) as well as floristic composition in 2015. The list of flora was made in the lysimeters during the growing season 2015. Also phytosociological records were taken applying the classic Braun-Blanquet's method, according to Dzwonko (2008): 5 - range of cover 75-100\%, 4 - range of cover $50-75 \%, 3$ - range of cover $25-50 \%, 2$ - range of cover $5-25 \%, 1$ - range of cover $1-5 \%,+-$ range of cover $<1 \%$. Plant communities have also been distinguished. Syngenesis (origin) of recognized phytocoenoses was characterized based on the work by Brzeg and Wojterska (2001) (after Faliński 1969). Area studied adjacent to a heavily shaded forest and scrub area dominated by Alnus glutinosa Gaertn., Betula pendula Roth, Populus tremula L.

Collective soil samples were taken from the superlayers, in which the following indicators were determined:

- granulometric composition by means of Casagrande method with Prószyński modifications; sand content by sieve method; division of granulometric fractions was made according to PSSS (2009);

- $\mathrm{pH}$ applying potentiometry in $1 \mathrm{~mol} \cdot \mathrm{dm}^{-3}$ potassium chloride solution at weight ratio soil/solution of $1: 2.5$;

- total contents of $\mathrm{C}$ and $\mathrm{N}$ using elemental CNS analyzer;

- available phosphorus and potassium content by means of the Egner-Riehm method;

- available magnesium content by the Schachtschabel method;

- content of microelements forms soluble in $1 \mathrm{M} \mathrm{HCl}: \mathrm{Mn}, \mathrm{Cu}, \mathrm{Zn}$.

Assessment of macro- and micronutrients forms available for plants was made according to Obojski and Strączyński (1995).

\section{RESULTS AND DISCUSSION}

The studied lysimeter areas were sown in 2003 with a mix of sodding grasses (Lolium perenne L., Festuca rubra L., Poa pratensis L.) - species useful in the reclamation of ashes (Rogalski et al. 1998, Kitczak et al. 2003). Jasionkowski et al. (2016) report that the species are capable of the spontaneous colonization of wet fly ash storage sites. The sown areas were subject to spontaneous transformation, because no cultivation activities were carried out after sowing. The soil and habitat conditions changing during the subsequent years on studied areas along with entering and colonization of the area by new species led 
to significant changes in vegetation of studied areas and development of plant communities synanthropic in nature.

The assessment of the established plant communities allowed us to verify the assumption that the introduction of organic materials will enable fast and effective covering of ashes with flora. Masu and Rus (2013) and Weber et al. (2015) found that the admixture of organic matter, such as sewage sludge, to the ashes facilitated the development of vegetation through improving the physical and chemical properties of the substrate. The addition of organic matter has also positively influenced the total number of soil bacteria and fungi (Pogrzeba et al. 2015).

The extent of the swine's density and its species composition on the surface of the examined lysimeters made it possible to identify communities and the potential direction of their succession, which is consistent with the conclusions of numerous authors (Klimont and Bulińska-Radomska 2009, Jasionkowski et al. 2016, Żołnierz et al. 2016, Urbanová et al. 2017).

In 2015, 12 years after the founding of experiment, the number of species has increased 13-fold (Table 1). The occurrence of 40 species of vascular plants was recorded. These plants inhabited the subsoil with a particle size of sandy loam (Table 2) in lysimeters 1 and 2, and loamy sand in 3 and 4 (PSSS 2009). A similar increase in the diversity of flora was obtained by Dyguś and Sienkiewicz (2014) studying the vegetation cover formed on the surface of the post-soda lime landfill in Janikowo. Thirteen years after reclamation, the local biodiversity measured by species abundance increased more than 15 times. Also Klimont et al. (2015) on deposits of flotation lime used for reclamation of the hole mine of sulfur, found an annual increase in the number of herbaceous plant species.

Table 1. The number of plant species according to some environmental groups found in lysimeters in the years 2003/2015

\begin{tabular}{lcccccc}
\hline \multirow{2}{*}{ Lysimeters } & \multirow{2}{*}{$\begin{array}{c}\text { Number of } \\
\text { plant species }\end{array}$} & grass & legumes & ruderal & meadow & forest \\
\cline { 3 - 7 }$\Sigma$ & $3 / 40$ & $3 / 2$ & $0 / 5$ & $0 / 24$ & $0 / 4$ & $0 / 4$ \\
\hline L-1 & $3 / 14$ & $3 / 1$ & $0 / 2$ & $0 / 8$ & $0 / 2$ & $0 / 1$ \\
\hline L-2 & $3 / 13$ & $3 / 1$ & $0 / 1$ & $0 / 4$ & $0 / 3$ & $0 / 2$ \\
\hline L-3 & $3 / 15$ & $3 / 2$ & $0 / 2$ & $0 / 13$ & $0 / 1$ & $0 / 1$ \\
\hline L-4 & $3 / 20$ & $3 / 2$ & $0 / 3$ & $0 / 13$ & $0 / 1$ & $0 / 1$ \\
\hline
\end{tabular}

Superlayer 1 (L-1 and L-2) was characterized by the alkaline character, while superlayer 2 containing significantly less calcium carbonate, was neutral (Table 2). These differences should be attributed to the composition of superlayers. As it was presented in Methods, superlayer 1 was composed of the mixture of ash and peat, whereas superlayer 2 did not contain ash at all, and half of its 
volume was sewage sludge. As it was shown by Klimont and Bulińska-Radomska (2009), introducing the municipal sludge at the rate of $350 \mathrm{~m}^{3} \cdot \mathrm{ha}^{-1}$ to ash resulted in some $\mathrm{pH}$ decrease. However, studies by Joniec (2013) have indicated that applying sludge to strongly acidic soils ( $\mathrm{pH}$ in $\mathrm{KCl} 4.1-4.3)$ caused considerable $\mathrm{pH}$ increase, which allows to conclude that remarkable acidification of superlayer 2 cannot be expected.

In both superlayers, similar total contents of nitrogen were recorded, while in superlayer 1, significantly higher amount of total carbon than in superlayer 2 was found (Table 2), although the latter contained much more organic matter at the time of formation (conifer bark, sludge and composts) than the former. Because of different carbon content, superlayer 1 was characterized by a $2-3$-fold larger $\mathrm{C}: \mathrm{N}$ ratio than superlayer 2, in which the ratio $\mathrm{C}: \mathrm{N}$ was similar to that described by Kwiatkowska-Malina (2015), and being within the standard range for Polish arable soils. Evaluation of the content of available macro- and microelements in the soils (Table 3) carried out according to the criteria by Obojski and Strączyński (1995) showed that the abundance in magnesium and phosphorus was very high, in zinc and copper - high, and in manganese - average. This allows the supposition that their bioavailability did not influence the diversity in the species composition of the sward, despite significant differences in the content of available forms of micronutrients. The content of available potassium showed no differentiation (Table 3), but due to differences in particle size of the superlayers, its abundance in lysimeters 1 and 2 was low, while in lysimeters 3 and 4 - average.

Table 2. Texture and selected chemical properties of soils

\begin{tabular}{|c|c|c|c|c|c|c|c|}
\hline \multirow{3}{*}{ Lysimeters } & \multicolumn{3}{|c|}{ Particle size (mm) } & \multirow{3}{*}{$\mathrm{pH}_{\mathrm{KCl}}$} & $\mathrm{CaCO}_{3}$ & $\mathrm{C}$ & \multirow{3}{*}{$\mathrm{C}: \mathrm{N}$} \\
\hline & $2.0-0.05$ & $0.05-0.002$ & $<0.002$ & & \multirow{2}{*}{\multicolumn{2}{|c|}{$\mathrm{gkg}^{-1}$}} & \\
\hline & \multicolumn{3}{|c|}{$\%$} & & & & \\
\hline L-1 & 63.2 & 34.8 & 2.0 & 7.51 & 13.9 & 57.3 & 24.9 \\
\hline $\mathrm{L}-2$ & 66.1 & 29.9 & 4.0 & 7.61 & 16.9 & 57.2 & 33.0 \\
\hline L-3 & 81.0 & 13.0 & 6.0 & 7.00 & 5.6 & 25.0 & 15.2 \\
\hline L-4 & 84.1 & 10.0 & 6.0 & 6.68 & 5.4 & 24.1 & 12.4 \\
\hline
\end{tabular}

Table 3. The content of available forms of macro- and micronutrients

\begin{tabular}{cccc|ccc}
\hline \multirow{2}{*}{ Lysimeters } & $\mathrm{Mg}$ & $\mathrm{P}$ & $\mathrm{K}$ & $\mathrm{Mn}$ & $\mathrm{Zn}$ & $\mathrm{Cu}$ \\
\cline { 2 - 7 } & \multicolumn{7}{c}{$\mathrm{mg} \cdot 100 \mathrm{~g}^{-1}$} & & $\mathrm{mg} \cdot \mathrm{kg}^{-1}$ & \\
\hline L-1 & 34.2 & 14.6 & 13.8 & 153 & 21.2 & 10.11 \\
\hline L-2 & 22.6 & 14.0 & 11.7 & 154 & 20.5 & 10.15 \\
\hline L-3 & 10.9 & 19.5 & 12.6 & 111 & 70.6 & 12.75 \\
\hline L-4 & 10.9 & 16.4 & 13.4 & 117 & 79.3 & 13.88 \\
\hline
\end{tabular}


Table 4. Characteristics of communities identified in soil lysimeters in 2003 (A) and 2015 (B)

\begin{tabular}{|c|c|c|c|c|c|c|c|c|}
\hline Year of research & $\mathrm{A}$ & $\mathrm{A}$ & A & A & $\mathrm{B}$ & $\mathrm{B}$ & $\mathrm{B}$ & $\mathrm{B}$ \\
\hline Number of lysimeters & L-1 & L-2 & L-3 & L-4 & L-1 & L-2 & L-3 & L-4 \\
\hline \multicolumn{9}{|l|}{ I. Cl. Molinio-Arrhenatheretea } \\
\hline Festuca rubra & $3^{1}$ & 3 & 3 & 3 & 4 & 4 & 1 & 3 \\
\hline Potentilla reptans & . & . & . & . & 2 & 3 & 1 & . \\
\hline Dactylis glomerata & . & . & . & . & . & . & 3 & 1 \\
\hline Vicia cracca & . & . & . & . & . & . & 1 & 1 \\
\hline Lolium perenne & 4 & 4 & 4 & 4 & . & . & + & . \\
\hline Poa pratensis & 1 & 1 & 1 & 1 & . & . & . & + \\
\hline \multicolumn{9}{|l|}{ II. Cl. Artemisietea vulgaris } \\
\hline Ballota nigra & $\cdot$ & . & . & . & . & . & 3 & . \\
\hline Fallopia dumetorum & . & . & . & . & . & . & 2 & 1 \\
\hline Glechoma hederacea & . & . & . & . & . & . & 1 & 2 \\
\hline Rubus caesius & . & . & . & . & . & . & 1 & 2 \\
\hline Urtica dioica & . & . & . & . & . & . & 2 & + \\
\hline Melandrium album & . & . & . & . & 2 & . & + & . \\
\hline Cirsium arvense & . & . & . & . & . & 2 & . & . \\
\hline Medicago lupulina & . & . & . & . & 1 & . & . & + \\
\hline Artemisia vulgaris & . & . & . & . & 1 & 1 & . & + \\
\hline Berteroa incana & . & . & . & . & 1 & & 1 & 1 \\
\hline Galium aparine & . & . & . & . & . & . & + & 1 \\
\hline Linaria vulgaris & . & . & . & . & . & 1 & 1 & . \\
\hline \multicolumn{9}{|l|}{ III. Cl. Stellarietea mediae } \\
\hline Vicia angustifolia & . & . & . & . & 1 & 2 & 1 & + \\
\hline Galeopsis tetrahit & . & . & . & . & 1 & 1 & 1 & 1 \\
\hline Vicia hirsuta & . & . & . & . & 1 & 2 & . & . \\
\hline Lactuca serriola & . & . & . & . & . & . & 1 & 1 \\
\hline \multicolumn{9}{|l|}{ IV. Others } \\
\hline Calamagrostis epigejos & . & . & . & . & 3 & 1 & . & . \\
\hline Humulus lupulus & . & . & . & . & . & . & . & 2 \\
\hline Clematis vitalba & . & . & . & . & . & + & 1 & . \\
\hline Hieracium umbellatum & . & . & . & . & . & - & + & 1 \\
\hline \multicolumn{9}{|c|}{$\begin{array}{l}\text { Sporadic species (A): I. Achillea millefolium (L-2) 1, Agrostis stolonifera (L-4) 1, Rumex } \\
\text { acetosa (L-2) 1, Lysimachia vulgaris (L-2) 1; II. Chaerophyllum temulum (L-4) 1, Cardus } \\
\text { crispus (L-4) 1, Poa nemoralis (L-2) +, Solidago canadensis (L-1) 1, Tanace tum vulgare (L-1) } \\
\text { 1, Veronica chamaedrys (L-1) 1; III. Chenopodium album (L-3) +, Polygonum aviculare (L-3) } \\
\text { +, IV. Stachys sylvatica (L-1) 1, Sambucus nigra c (L-4) + }\end{array}$} \\
\hline
\end{tabular}

${ }^{1}$ Braun-Blanquet's scale: 5 - range of cover $75-100 \% ; 4$ - range of cover $50-75 \% ; 3$ - range of cover $25-50 \% ; 2$ - range of cover $5-25 \% ; 1$ - range of cover $1-5 \%$; + range of cover $<1 \%$; $\mathrm{Cl}$ - class of vegetation

In 2015, share of Lolium perenne L. in the species composition was neglected, despite that in 2003, it was introduced as a dominated sodding grass species (Table 4). 
On the area L-1, regardless of a remarkable percentage of Festuca rubra L., it was recorded a dynamic increase and enhancement of the range by Calamagrostis epigejos (L.) Roth making a hull form of Calamagrostietum epigeji Juraszek 1928 association developed both in natural and anthropogenic habitats. Its presence can indicate that suppression processes of the pioneer vegetation by species that is strongly expansive and able to colonizing, begin to occur (Mitrović et al. 2008, Klimont et al. 2015). It can lead to the elimination of many plant species, at the same time making possible to tree and scrub development towards formation of shrub and forest communities (Kostuch and Twardy 2006). As it was presented by Dostál and Kováŕ (2014), Calamagrostis epigejos (L.) Roth, even on areas with unfavorable subsoil conditions (flotation sediments of alkaline character), can be efficiently widespread due to anemochory and subsequently vegetative reproduction forming phytocoenoses in dry habitats (Kutyna and Dziubak 2005). This species, characteristic of porro habitats, is accompanied by Artemisia vulgaris L. and Melandrium album (Mill.) Garcke - ruderal plants whose development can quickly contribute to the reduction of the floristic diversity of the habitat.

The species composition at L-2 indicated better conditions for the development of meadow plants. Festuca rubra L. dominated, it was a co-dominant species of Potentilla reptans L. Unlike L-1, Achillea millefolium L., Rumex acetosa L. and Lysimachia vulgaris $\mathrm{L}$ were found. It was probably favored by the development of valuable species from the family of legumes, binding free nitrogen from the air - Vicia angustifolia L. and Vicia hirsuta (L.) S.F. Gray (species of class Stellarietea mediae). They also appeared perennial species Artemisia vulgaris L. and Cirsium arvense (L.) Scop.), as well as class Artemisietea vulgaris, was observed. It may indicate the initialized stage of Artemisio-Tanacetetum vulgaris Br.-B1. 1931 corr. 1949 association.

In lysimeter L-3, there was considerable share of ruderal species (Table 4) that initialize typically ruderal nitrophilous association Leonuro-Ballotetum nigrae Slavn. 1951, and only hull-developed with a single characteristic species. Among herbaceous plants, ruderal-segetal vegetation prevailed - 14 species of classes: Artemisietea, Epilobietea angustifolii and Stellarietea mediae. Remaining 6 species were meadow-pasture ones of classes Molinio-Arrhenatheretea and Koelerio glaucae-Corynephoretea canescentis as well as a single shrub species of class Rhamno-Prunetea. Dyguś (2013) referred to Leonuro-Ballotetum nigrae Slavn. 1951 as one of the most developed communities in its optimum developmental stage on landfill Radiowo. In lysimeter 4, ruderal species of Artemisietea class were also present, however, Rubus caesius preferring dry, sunny and nitrophilous habitats, was also developed. Further growth of this species in the community on the studied area should be expected. A significant share of ruderal species within lysimeters 3 and 4 (Table 4) is consistent with that was shown by Dyguś and Sienkiewicz (2014). They presented that spots of vegetation developing on reclaimed ash substrate formed the meadow-ruderal com- 
munity Sisymbrium loeselii-Artemisia vulgaris with small patches of typically ruderal aggregations of nitrophilous annual species. This type of phytocoenosis was referred to by Brzeg and Wojterska (2001) as synanthropic ruderal specialized communities.

The only species, the occurrence of which can be assumed that it is associated with differences in grain size of the superlayers was Hieracium umbellatum L. of class Koelerio glaucae-Corynephoretea canescentis characteristic for sandy meadows. It was found in lysimeters 3 and 4, and after Zaniewski et al. (2015), also present on forest post-fire sites on sandy areas. Contrary to earlier assumptions about the impact of the forest-shrub community adjacent to the studied subject, there was no significant share of species associated with this habitat in the sward. The presence of only single species, such as Stachys sylvatica L. - typically forest of class Querco-Fagetea, Humulus lupulus L. - shrub with Salicetea purpureae and Clematis vitalba L. of shrub formation, class Rhamno-Prunetea, was confirmed.

Syngenesis of distinguished plant associations and communities on analyzed areas confirmed the superiority of synanthropic ruderal communities represented by nitrophilous tall herbs:

Class: Artemisietea vulgaris Lohm., Prsg et R. Tx. in R. Tx. 1950

Subclass: Artemisienea vulgaris

Order: Onopordetalia acanthii Br.-B1. et R. Tx. 1943 em Görs 1966

Alliance: Onopordion acanthii Br.-B1. 1926

Sub-alliance: Dauco-Melilotenion Görs 1966

Association: Artemisio-Tanacetetum vulgaris Br.-B1. 1931

corr. 1949 (synanthropic ruderal common community that can occur on the whole area) (Brzeg and Wojterska 2001)

Order: Artemisietalia vulgaris Lohm. in R. Tx. 1947

Alliance: Arction lappae R. Tx. 1937 em 1950

Association: Leonuro-Ballotetum nigrae Slavn. 1951

(synanthropic ruderal common community that can occur on the whole area) (Brzeg and Wojterska 2001)

Subclass: Galio-Urticenea (Pass. 1967)

Order: Convolvuletalia sepium R. Tx. 1950

Community with Rubus caesius (synanthropic ruderal common community) (Brzeg and Wojterska 2001)

There was also found the community associated with initial and terminal developmental stages of the forest:

Class: Epilobietea angustifolii R. Tx. et Prsg 1950

Order: Atropetalia Vlieg 1937 
Alliance: Epilobion angustifolii (Rubel 1933) Soo 1933

Community: Calamagrostietum epigeji Juraszek 1928 (common and widespread natural auxochoric community) (Brzeg and Wojterska 2001)

Due to the lack of the factors limiting the plant growth and differentiating the superlayers, there was no obvious impact on the syntaxonomic membership of communities. In the studied communities, abundance of species was lower as compared to natural habitats. However, it should be expected their further development towards fully developed phytocoenoses: Calamagrostietum epigeji Juraszek 1928 (in L-1), Artemisio-Tanacetetum Br-Bl. 1931 corr. 1949 (in L-2), Leonuro-Ballotetum nigrae Slavn. 1951 (in L-3), and community with Rubus caesius (in L-4).

Earlier thesis about the influence of neighboring forest community on species composition of the forest object vegetation has not been confirmed. Three forest and scrub species (Clematis vitalba L., Humulus lupulus L., Stachys sylvatica L.) had only $7.5 \%$ share in the total flora of the studied objects, while on areas of the coal mine "Jan Kanty" in Jaworzno, share of deciduous forest species was 16\% (Jędrzejko and Olszewski 2008).

\section{CONCLUSIONS}

1. Among the established plant communities, the synanthropic rudimentary Artemisio-Tanacetetum vulgaris Br.-B1. 1931 corr. 1949 (L-2) and Leonuro-Ballotetum nigrae Slavn. 1951 (L-3) complexes dominated, a community with Rubus caesius (L-4). Calamagrostietum epigeji Juraszek 1928 was found only in lysimeter 1, associated with the initial and terminal development stages of the forest.

2. The species composition in lysimeter 1 can indicate that the pioneer planting processes of Calamagrostis epigejos (L.) Roth are beginning to take place. In lysimeter 2, the presence of Artemisia vulgaris L. and Cirsium arvense (L.) Scop. allows to conclude about the development towards stable communities of high aggregate perennials. In lysimeter 3 , the further development of Urtica dioica can contribute to the reduction of the fitodiversity of the Leonuro-Ballotetum nigrae Slavn. complex 1951. In the last lysimeter, one should expect a further increase in the participation of Rubus caesius in the community.

3. The assumption about the infiltration of forest and shrub species from the neighboring forest structure and the settling of lysimeter surfaces by them has not been confirmed. The share of the taxons in the flora of the studied subjects was negligible $-7.5 \%$, in the form of Clematis vitalba L., Humulus lupulus L., Stachys sylvatica L. 
4. There was a significant increase in the species diversity of plants growing on the lysimeter, from three species (Lolium perenne L., Festuca rubra L., Poa pratensis L.) to forty. Among the sown grasses, only Festuca rubra L. retained a significant share in covering the undergrowth. The remaining species were sporadic.

5. The overlays varied in terms of grain size and reaction. Overlay 1 was sandy clay with basic $\mathrm{pH}\left(\mathrm{pH}_{\mathrm{KCl}} 7.51-7.61\right)$, and overlay 2 was clayey sand with neutral $\mathrm{pH}\left(\mathrm{pH}_{\mathrm{KCl}} 6.68-7.00\right)$. The value of $\mathrm{C}: \mathrm{N}$ ratio in overlay 1 was twice as high (28.9) as in overlay 2 (13.8) in which it corresponded to the values recorded on arable land.

6. The content of assimilable $\mathrm{P}, \mathrm{Mg}, \mathrm{Zn}, \mathrm{Cu}, \mathrm{Mn}$ forms did not differentiate the conditions of vegetation development. The exception was potassium, the amount of it in overlay 1 was low, and in overlay 2 - medium.

7. The overlays, allowing ashes to perform soil functions, provided conditions for the development of vegetation protecting the neighboring areas against ash pollution as a result of erosion processes.

8. The observed species composition of the studied lysimeter surfaces indicates the potential direction of the succession, which allows to take measures to prevent the reduction of fitodiversity, as associated with the dominance of shrubs or other species with woody surface shoots.

\section{REFERENCES}

[1] Bajor, P., Bulińska-Radomska, Z., Klimont, K., Osińska, A., 2014. Evaluation of the development of vegetation on incineration ash disposal area fertilized with sewage sludge (in Polish). Problems of Agricultural Engineering, 22(2): 51-61.

[2] Balcerkiewicz, S., Pawlak, G., 2008. Formation and persistence of plant communities under extreme conditions - selected aspects. Ecological Question, 9: 9-14.

[3] Brzeg, A., Wojterska, H., 2001. Vegetation cover of Wielkopolska and the Southern Pomerania Lakelands (in Polish). In: M. Wojterska (ed.), A guide to field sessions of the $52^{\text {nd }}$ Convention of the Polish Botanical 24-28.09.2001. Poznan, Bogucki Wydawnictwo Naukowe, pp. 39-110.

[4] Ciećko, Z., Żołnowski, A.C., Madej, M., Wasiak, G., Lisowski, J., Rolka, E., 2015. The longterm impact of ameliorating doses of hard coal fly ash on shaping the content of selected microelements in agricultural soil. Polish Journal of Soil Science, 48(1): 1-12.

[5] Dostál, P., Kovář, P., 2014. Seed rain and seed persistence of Calamagrostis epigejos (L.) Roth in extreme ecotoxicological conditions at an abandoned ore-washery sedimentation basin. Journal of Landscape Ecology, 6(2): 17-33.

[6] Dyguś, K.H., 2013. Vegetation of two municipal waste landfills of Mazovia (in Polish). Ecological Engineering, 34: 96-120.

[7] Dyguś, K.H., Sienkiewicz, J., 2014. Assessment of vegetation cover on soda waste disposal site at Janikowo, following 13-year-long reclamation (in Polish). Ecological Engineering, 36: 65-97.

[8] Dzwonko, Z., 2008. Guide to phytosociological research (in Polish). Sorus, p. 308.

[9] Faliński, J.B., 1969. Autogenous and anthropogenic communities. Attempt to identify and classification. Phytosociological discussions (4) (in Polish). Polish Ecology, 15(2): 173-182. 
[10] Gamrat, R., Gałczyńska, M., Majdosz, M., Łysko, A., 2016. Importance of the buffer zone of the water intake for the maintenance of agrosystem phytodiversity. Agrofor International Journal, 1(2): 103-111.

[11] Jasionkowski, R., Wojciechowska, A., Kamiński, D., Piernik, A., 2016. Meadow species in the early stages of succession on the ash settler of power plant EDF Torun SA in Torun', Poland. Ecological Questions, 23/2016: 79-86.

[12] Jędrzejko, K., Olszewski, P., 2008. Characteristics of species of the vascular flora on the liquidated "Jan Kanty" coal-mine in Jaworzno area (in Polish). Research Reports of Central Mining Institute, Mining \& Environment, Quarterly, 2: 19-35.

[13] Joniec, J., 2013. Microbiological transformations of N, S and P in degraded soil subjected to one-year remediation with various wastes. Polish Journal of Soil Science, 46(1): 61-75.

[14] Kitczak, T., Czyż, H., Trzaskoś, M., Gos, A., 2003. The durability of sod according to the way of management of ash-slag pile (in Polish). Biuletyn Instytutu Hodowli i Aklimatyzacji Roślin, 225: 365-370.

[15] Klimont, K., Bulińska-Radomska, Z., 2009. The study on application of selected grass species to reinforcing the dumps of furnace ashes from heat and power stations (in Polish). Problems of Agricultural Engineering, 2: 135-144.

[16] Klimont, K., Bulińska-Radomska, Z., Górka, J., 2015. Succession of flora communities on soilless deposit of post flotation lime on the post-mining area of sulfur mine (in Polish). Biuletyn Instytutu Hodowli i Aklimatyzacji Roœlin, 275: 111-124.

[17] Kostuch, R., Twardy, S., 2006. Plants settled in the metallurgical dumps of the Nowa Huta blast-furnace (in Polish). Journal of Academic University of Environmental and Life Sciences, Agriculture, Wrocław, 88(545): 147-156.

[18] Kutyna, I., Dziubak, K., 2005. Phytocoenoses on the landfill sludge flotation "Gilów”. Association of Arrhenatheretum elatiorois and Echio-Melilotetum (in Polish). Folia Pomeranae Universitatis Technologiae Stetinensis. Agricultura, Alimentaria, Piscaria et Zootechnica, 244(99): 113-124.

[19] Kwiatkowska-Malina, J., 2015. The comparison of the structure of humic acids from soil amended with different sources of organic matter. Polish Journal of Soil Science, 48(1): $57-64$.

[20] Majtkowski, W., Majtkowska, G., 2012. Phytosanitary functions of plants used for the reclamation of the heap of ashes in Sowlany near Biatystok (in Polish). Biuletyn Instytutu Hodowli i Aklimatyzacji Roœlin, 263: 55-63.

[21] Masu, S., Rus, V., 2013. Studies regarding the establishment of perennial plant communities stimulated with biosolids on fly ash dumps. Journal of Environmental Protection and Ecology, 14(1): 204-208.

[22] Mitrović, M., Pavlović, P., Lakusić, D., Djurdjević, L., Stevanović, B., Kostić, O., Gajić, G., 2008. The potential of Festuca rubra and Calamagrostis epigejos for the revegetation of fly ash deposits. Science of the Total Environment, 15, 407(1): 338-47.

[23] Obojski, J., Strączyński, S., 1995. Reaction and wealth of soils in Poland in macro and micronutrients (in Polish). IUNG Puławy, p. 48.

[24] PSSS, 2009. Particle size distribution and textural classes of soils and mineral materials classification of Polish Society of Soil Science 2008 (in Polish). Soil Science Annual, 60(2): $5-16$.

[25] Pogrzeba, M., Galimska-Stypa, R., Krzyżak, J., Sas-Nowosielska, A., 2015. Sewage sludge and fly ash mixture as an alternative for decontaminating lead and zinc ore regions. Environmental Monitoring and Assessment, 187: 41-20.

[26] Rogalski, M., Kapela, A., Kardyńska, S., Wieczorek, A., Kryszak, J., 1998. Studies on initial growth and development of some grass species grown on ashes from the Dolna Odra power plant (in Polish). Archives of Environmental Protection, 24(3): 123-128. 
[27] Stankowski, S., Niedźwiecki, E., Wojcieszczuk, T., Meller, E., Malinowski, R., Sammel, A., Maciorowski, R., Wojcieszczuk, M., Szuberla, U., Ułasik, S., Dobrohorska, H., Owsicka, A., 2005. The investigations to determine the impact of rainwaters penetrating the layers of ash-slags on the environment, realized in lysimeters in the power plant "Dolna Odra" in Nowe Czarnowo (in Polish). Research Report for the period September-November 2005, Agricultural University of Szczecin, pp. 44.

[28] Urbanová, J., Kovář, P., Dostál, P., 2017. What processes shape early-successional vegetation in fly ash and mine tailings? Plant Ecology, 218: 127-137.

[29] Weber, J., Strączyńska, S., Kocowicz, A., Gilewska, M., Bogacz, A., Gwiżdż, M., Debicka, M., 2015. Properties of soil materials derived from fly ash 11 years after revegetation of post-mining excavation. CATENA, 133: 250-254.

[30] Woch, M.W., 2012. New and rare synanthropic plant species of the Polish flora on dormant sedimentation ponds of the Siersza Power Plant (in Polish). Fragmenta Floristica et Geobotanica Polonica, 19(1): 29-38.

[31] Woch, M.W., Radwańska, M., Stefanowicz, A.N., 2013. Flora of spoil heaps after hard coal mining in Trzebinia (southern Poland): effect of substratum properties. Acta Botanica Croatica, 72(2): 237-256.

[32] Zaniewski, P.T., Siedlecki, Ł., Potoczny, B., Krasińska, R., Pestka, Z., Bernatowicz, A., 2015. Species richness of vascular plants in phytocenoses regenerating on area after the fire on dune areas of the Lower Basin of the Biebrza valley (in Polish). Proceedings of the Center for Nature and Forestry Education, 17, 42(1): 172-174.

[33] Żołnierz, L., Weber, J., Gilewska, M., Strączyńska, S., Pruchniewicz, D., 2016. The spontaneous development of understory vegetation on reclaimed and afforested post-mine excavation filled with fly ash. CATENA, 136: 84-90. 